\title{
CHANGES OF PROTEIN FRACTIONS IN WHEAT FLOUR CAUSED BY ADDITIVES
}

\author{
P. Pečivová, I. Burešová, J. Hrabě
}

Received: September 25, 2009

\begin{abstract}
PEČIVOVÁ, P., BUREŠOVÁ, I., HRABĚ, J.: Changes of protein fractions in wheat flour caused by additives. Acta univ. agric. et silvic. Mendel. Brun., 2010, LVIII, No. 1, pp. 123-130

The influence of different combinations of reducing and oxidising agents (L-cysteine hydrochloride monohydrate + L-ascorbic acid, inactivated dry yeast + L-ascorbic acid, L-threonine + L-ascorbic acid, L-tryptophan + L-ascorbic acid) on the change in the proportion of glutenins, gliadins, albumins, globulins in wheat flour was investigated.

Different concentrations of amino acid combinations were added to wheat flour. By means of Size Exclusion High performance liquid chromatography (SE-HPLC), the changes in protein fractions caused by individual concentrations of amino acid combinations were evaluated against the control sample (pure wheat flour).

It was detected that the mixture of flour + L-ascorbic acid + L-cysteine hydrochloride monohydrate had the stronger reducing effect than the mixture of flour + L-ascorbic acid + inactivated dry yeast. On the other hand, the mixture of flour + L-ascorbic acid + L-tryptophan had the stronger oxidising effect than the mixture of flour + L-ascorbic acid + L-threonine.
\end{abstract}

amino acid, oxidising agent, reducing agent, flour, mixture

Flour protein content is probably the most important property of wheat flour. Wheat endosperm proteins are divided into two main fractions, monomeric and polymeric proteins. The monomeric fraction includes gliadins, albumins, and globulins. Albumins and globulins are considered functional proteins, whereas gliadins are referred to as storage proteins. Polymeric fraction mainly consists of glutenin polymers composed of high-molecular-weight glutenin subunits (HMW-GS) and low-molecular-weight glutenin subunits (LMW-GS) associated together by intermolecular disulfide bonds (Rhazi et al., 2009).

Gliadins and glutenins constitute the gluten proteins that are considered the most important fractions responsible for variations in bread-making quality (Weegels et al., 1996). The breadmaking quality of wheat flour is largely determined by the quality of the gluten fraction. The glutenin polymer structure, size distribution and subunit composition and the gliadin/glutenin ratio are major factors in determining gluten quality and, hence, the breadmaking potential of wheat flour (Khatkar et al., 1995; Ciaffi et al., 1996; Janssen et al., 1996; Veraverbeke et al., 1998; Uthayakumaran et al., 1999; D’ Ovidio and
Masci, 2004; Joye et al., 2009). Gliadins are monomeric proteins that consist of single chain polypeptides and contribute to the viscous properties of dough; glutenins are polymeric proteins in which the individual subunits are linked by disulphide bonds (Field et al., 1983a; 1983b) and are thought to have molecular weights ranging from a few hundred thousand to many millions dalton (Da). These glutenin polymers have been described as "nature's largest polymers" (Wrigley, 1996) and they are the main components responsible for differences in end-use quality among different flour cultivars (Weegels et al., 1996; Mendichi et al., 2008). Glutenin subunits, of both low (LMW-GS) and high (HMW-GS) molecular weight, exhibit both inter- and intra-chain disulphide bonding, and are bound together in glutenin polymers, the size of which is strongly correlated with gluten quality (Gupta et al., 1993; Gupta et al., 1995). Protein strength is an inherent characteristic, but the amount of protein present can be influenced by the conditions under which wheats are grown (e.g. sulphur deficiency, heat or water stress). Non-gluten proteins include albumins (water extractable) and globulins (dilute salt medium extract- 
able) which comprise metabolic proteins (enzymes or inhibitors) and minor storage proteins (Joye et al., 2009).

Several agents present in wheat can potentially affect the breadmaking performance of the flour (Joye et al., 2009). Although the dough and bread characteristics strongly depend on the breadmaking recipe and procedure, the type and properties of the flour used also play an important role. The dough properties and breadmaking quality of flour are affected by variation in the levels of natural reducing or oxidising agents in wheat flour. Oxidising agents generally promote SS bond formation and, hence, minimise SH/SS interchange with positive impacts on loaf volume, oven rise and oven rise time. In contrast, reducing agents promote $\mathrm{SH} / \mathrm{SS}$ interchange reactions, and result in weaker dough, reduced mixing time and improved dough machinability (Joye et al., 2009). Baking quality can be accelerated by improvers that modify the physical properties of gluten during fermentation. Dough improvers are often added to flour to improve dough elasticity or extensibility and baking quality. For better acting, a dough improver often consists of oxidising and reducing agents. Reducing agents, such as glutathione, which is tripeptide ( $\gamma$-glutamylcysteinylglycine) containing two carboxylic acid groups, one free amino group and a SH group (Joye et al., 2009), and cysteine (Morita et al., 1996), reduce the kneading force and dough fermentation time by accelerating gluten disrupture and then the number of sulfhydryl groups increases (Biebaut, 1991).

The oxidants increase the elastic/viscous ratio in dough. The type of action is dependent on the type of oxidant. Ascorbic acid, although being itself a reducing agent, can exert an oxidising effect on the dough properties after its oxidation by atmospheric oxygen. The oxidation product is dehydroascorbic acid (Hrušková and Novotná, 2003). Ascorbic acid reformes gluten to a three-dimensional matrix and oxidizes the SH group to SS bond, which increases the dough strength by retaining gas, and thus enlarges the bread volume. It is generally accepted that the rheological properties of dough and its three-dimensional network are dependent on the arrangement and number of disulfide bonds and sulfhydryl groups of the protein. A small amount of cysteine or reduced glutathione dramatically in- crease the extensibility of dough (Bloksma, 1972; Dong and Hoseney, 1995). However, there has not been found much information about the influence of amino acids as L-threonine and L-tryptophan on the rheological properties of dough. Amino acids as L-threonine and L-tryptophan are normally present in minor amount in wheat flour. These amino acids belong to essential amino acids and their addition to the dough strengthen final bakery product thereby improve their quality (nutritional value). Hence, these two amino acids were investigated with the combination of ascorbic acid and their influence on the changes in HMW-GS and LMW-GS groups was analyzed. Good nutrition can lead to an impressive range of benefits. From the perspective of human capital, these include improvement in health, cognitive development and work capacity. From the viewpoint of development, they include greater economic and agricultural productivity, better education, improved workforce development as well as greater resilience to shocks induced by social, economic and natural causes. The evidence suggests that these benefits can be achieved at high levels of economic efficiency for a wide range of nutrition policy instruments (Golian, 2009).

The aim of this study was to evaluate the oxidising and reducing effect as the change on the proportion of the glutenins, gliadins, albumins, globulins, between pure wheat flour and wheat flour with the addition of different amounts of reducing and oxidising agent.

\section{MATERIALS AND METHODS}

\section{Flour}

For the assessment, common commercial wheat flour T 530 (quantitative parameters: moisture content $(\mathrm{MC})=14.3 \%$, gluten content in dry matter $(\mathrm{GC})=36.4 \%$, Falling number $(\mathrm{FN})=339 \mathrm{~s})$, provided by Penam, s.r.o. Kroměříž, Czech Republic, was used. It was used $1 \mathrm{~g}$ flour for each analysis.

Other information about flour was found by alveoconsistograf analysis (Chopin - Tripette \& Renauld, France) according to the methods AACC 54-30A and 54-50, respectively.

Alveograph and consistograph characteristics of investigated untreated flour are shown in table I.

I: Alveograph and consistograph characteristics of investigated untreated flour

\begin{tabular}{cccc}
\hline Alveograph characteristic & Value & Consistograph characteristic & Value \\
\hline $\mathrm{P}^{\mathrm{a}}$ & $95 \mathrm{mmH}_{2} \mathrm{O}$ & PrMax $^{\mathrm{e}}$ & $2237 \mathrm{mb}$ \\
$\mathrm{L}^{\mathrm{b}}$ & $89 \mathrm{~mm}$ & $\mathrm{TPrMax}^{\mathrm{f}}$ & $173 \mathrm{~s}$ \\
$\mathrm{P} / \mathrm{L}^{\mathrm{c}}$ & 1.06 & $\mathrm{Tol}^{\mathrm{g}}$ & $241 \mathrm{~s}$ \\
$\mathrm{~W}^{\mathrm{d}}$ & $28710 \mathrm{E}-4 \mathrm{~J}$ & $\mathrm{D} 250^{\mathrm{h}}$ & $197 \mathrm{mb}$ \\
& & $\mathrm{D} 450^{\mathrm{i}}$ & $742 \mathrm{mb}$ \\
\hline
\end{tabular}

$\mathrm{P}^{\mathrm{a}}$ - tenacity, $\mathrm{L}^{\mathrm{b}}$ - extensibility, $\mathrm{P} / \mathrm{L}^{\mathrm{c}}$ - configuration ratio, $\mathrm{W}^{\mathrm{d}}-$ deformation energy, $\operatorname{PrMax}$ - maximum pressure, TPrMax $^{\mathrm{f}}$ - time to reach maximum pressure, Tolg - time that pressure is higher than PrMax minus 20\%, D 250 - the drop in pressure at 250 seconds from PrMax minus 20\%, D 450i - the drop in pressure at 450 seconds from PrMax minus 20\%. *mb (millibar) - the device is calibrated on values $\mathrm{mb}$ 
II: The composition of individual samples $(\% w / w)$

\begin{tabular}{|c|c|c|c|}
\hline \multirow{2}{*}{ Sample } & \multicolumn{3}{|c|}{ Mixture composition (\% w/w) } \\
\hline & Flour & L-ascorbic acid & L-threonine/L-tryptophan \\
\hline THI/TRI ${ }^{a, w}$ & 62.50 & 18.75 & 18.75 \\
\hline TH3/TR3 $3^{\mathrm{c}, \mathrm{y}}$ & 50.00 & 15.00 & 35.00 \\
\hline TH4/TR4 ${ }^{\mathrm{d}, \mathrm{z}}$ & 45.45 & 13.64 & 40.91 \\
\hline $\mathrm{Cl}^{\mathrm{e}}$ & 75.19 & 22.56 & 2.26 \\
\hline$C 2^{\mathrm{f}}$ & 73.53 & 22.06 & 4.41 \\
\hline \multirow[t]{2}{*}{$\mathrm{C}^{\mathrm{g}}$} & 72.46 & 21.74 & 5.80 \\
\hline & Flour & L-ascorbic acid & Inactivated dry yeast \\
\hline
\end{tabular}

$\mathrm{THl} / \mathrm{TR} 1^{\mathrm{a}}$ mixture of flour $(62.50 \% \mathrm{w} / \mathrm{w}+\mathrm{L}$-ascorbic acid (18.75\% w/w) + L-threonine (18.75\% w/w)/ L-tryptophan (18.75\% $\mathrm{w} / \mathrm{w}), \mathrm{TH} 2 / \mathrm{TR}^{\mathrm{b}}$ mixture of flour $(55.56 \% \mathrm{w} / \mathrm{w}+\mathrm{L}$-ascorbic acid $(16.67 \% \mathrm{w} / \mathrm{w})+\mathrm{L}$-threonine $(27.78 \% \mathrm{w} / \mathrm{w}) /$ L-tryptophan (27.78\% w/w), TH3/TR3 ${ }^{\mathrm{c}}$ mixture of flour $(50.00 \% \mathrm{w} / \mathrm{w}+\mathrm{L}$-ascorbic acid $(15.00 \% \mathrm{w} / \mathrm{w})+\mathrm{L}$-threonine (35.00\% w/w)/ L-tryptophan $(35.00 \% \mathrm{w} / \mathrm{w}), \mathrm{TH} 4 / \mathrm{TR} 4^{\mathrm{d}}$ mixture of flour $(45.45 \% \mathrm{w} / \mathrm{w}+\mathrm{L}$-ascorbic acid $(13.64 \% \mathrm{w} / \mathrm{w})+\mathrm{L}-$ threonine $(40.91 \% \mathrm{w} / \mathrm{w}) /$ L-tryptophan (40.91\% w/w), Cl ${ }^{\mathrm{e}}$ mixture of flour $(75.19 \% \mathrm{w} / \mathrm{w}+\mathrm{L}$-ascorbic acid $(22.56 \% \mathrm{w} / \mathrm{w})+$ L-cysteine hydrochloride monohydrate $(2.26 \% \mathrm{w} / \mathrm{w}), \mathrm{C} 2^{\mathrm{f}}$ mixture of flour $(73.53 \% \mathrm{w} / \mathrm{w}+\mathrm{L}$-ascorbic acid $(22.06 \% \mathrm{w} / \mathrm{w})+\mathrm{L}$-cysteine hydrochloride monohydrate $(4.41 \% \mathrm{w} / \mathrm{w}), \mathrm{C}^{\mathrm{g}}$ mixture of flour $(72.46 \% \mathrm{w} / \mathrm{w}+\mathrm{L}$-ascorbic acid $(21.74 \% \mathrm{w} / \mathrm{w})+\mathrm{L}$-cysteine hydrochloride monohydrate $(5.80 \% \mathrm{w} / \mathrm{w}), \mathrm{IDY} \mathrm{I}^{\mathrm{h}}$ mixture of flour $(62.50 \% \mathrm{w} / \mathrm{w}+\mathrm{L}$-ascorbic acid $(18.75 \% \mathrm{w} / \mathrm{w})+$ inactivated dry yeast $(18.75 \% \mathrm{w} / \mathrm{w})$, IDY2 $2^{\mathrm{i}}$ mixture of flour $(55.56 \% \mathrm{w} / \mathrm{w}+\mathrm{L}$-ascorbic acid $(16.67 \% \mathrm{w} / \mathrm{w})+$ inactivated dry yeast $(27.78 \% \mathrm{w} / \mathrm{w})$, IDY ${ }^{j}$ mixture of flour $(50.00 \% \mathrm{w} / \mathrm{w}+\mathrm{L}$-ascorbic acid $(15.00 \% \mathrm{w} / \mathrm{w})+$ inactivated dry yeast $(35.00 \% \mathrm{w} / \mathrm{w})$

\section{Additives}

Different combinations of reducing and oxidising agents were selected.

Oxidising agents; amino acids as L-threonine and L-tryptophan (Merck KGaA, Darmstadt, Germany).

Reducing agents; amino acids as L-ascorbic acid (Merck KGaA, Darmstadt, Germany), L-cysteine hydrochloride monohydrate and inactivated dry yeast (Ireks GmbH, Eppelborn, Germany).

Mixtures always included wheat flour, L-ascorbic acid and selected additive (L-threonine, L-tryptophan, L-cysteine hydrochloride monohydrate, inactivated dry yeast). Constant ratio of wheat flour and L-ascorbic acid (23:77) was kept for each analysis.

The composition of individual samples is seen in table II.

These combinations of reducing and oxidising agents, especially combinations (L-ascorbic acid + L-tryptophan, L-ascorbic acid + L-threonine) has not been used for practical application yet.

\section{Methods}

The flour was extracted for 2 hours at $60^{\circ} \mathrm{C}$ in $0.1 \mathrm{M}$ phosphate buffer ( $\mathrm{pH}$ 6.9) containing $2 \%$ SDS. After centrifugation (at $15.000 \mathrm{rev}$./min.) supernatant was applied to a column Phenomenex BioSep-SECS4000 $(300 \times 7.8 \mathrm{~mm})$. The analysis was performed on a liquid chromatograph Shimadzu by means of SE-HPLC (Size exclusion High performance liquid chromatography) analysis according to (Dachkevitch and Autran, 1989). The mobile phase consisted of phosphate buffer ( $\mathrm{pH}$ 6.9) with the addition of $0.1 \%$ SDS. The spectra were detected at $214 \mathrm{~nm}$.

Proteinaceous fractions present in the sample were identified by means of standards of known molecular weights.

Example of chromatogram of the control sample (pure wheat flour) can be seen in figure 1 .

\section{RESULTS AND DISCUSSION}

Tables III-IV illustrate the peak characteristics of SE-HPLC spectra of the samples observed. The tables show the retention times and peak areas of the individual proteinaceous fractions as glutenins, gliadins, albumins and globulins. The tables show the values of pure flour along with the flour with different combinations of reducing and oxidising agents added.

As it is clear from table III, in the samples (C1-C3), different changes in spectrum characteristics occurred depending on the concentration of L-cysteine hydrochloride monohydrate. The peak areas detected in the $11^{\text {th }}$ minute were the largest in sample $\mathrm{Cl}$, i.e. in the sample with the lowest concentration $(2.26 \% \mathrm{w} / \mathrm{w})$ of L-cysteine hydrochloride monohydrate. The smallest peak area was found in sample $\mathrm{C} 2$. The peak areas detected in the $11^{\text {th }}$ minute in samples C3 has almost identical values. The peak area detected in the $16^{\text {th }}$ minute was decreasing (in comparation with C1; C2 23\%, C3 27\%) with the increasing concentration of L-cysteine hydrochloride monohydrate. On the other hand, the peak area of gliadins detected in the $18^{\text {th }}$ minute was gra- 


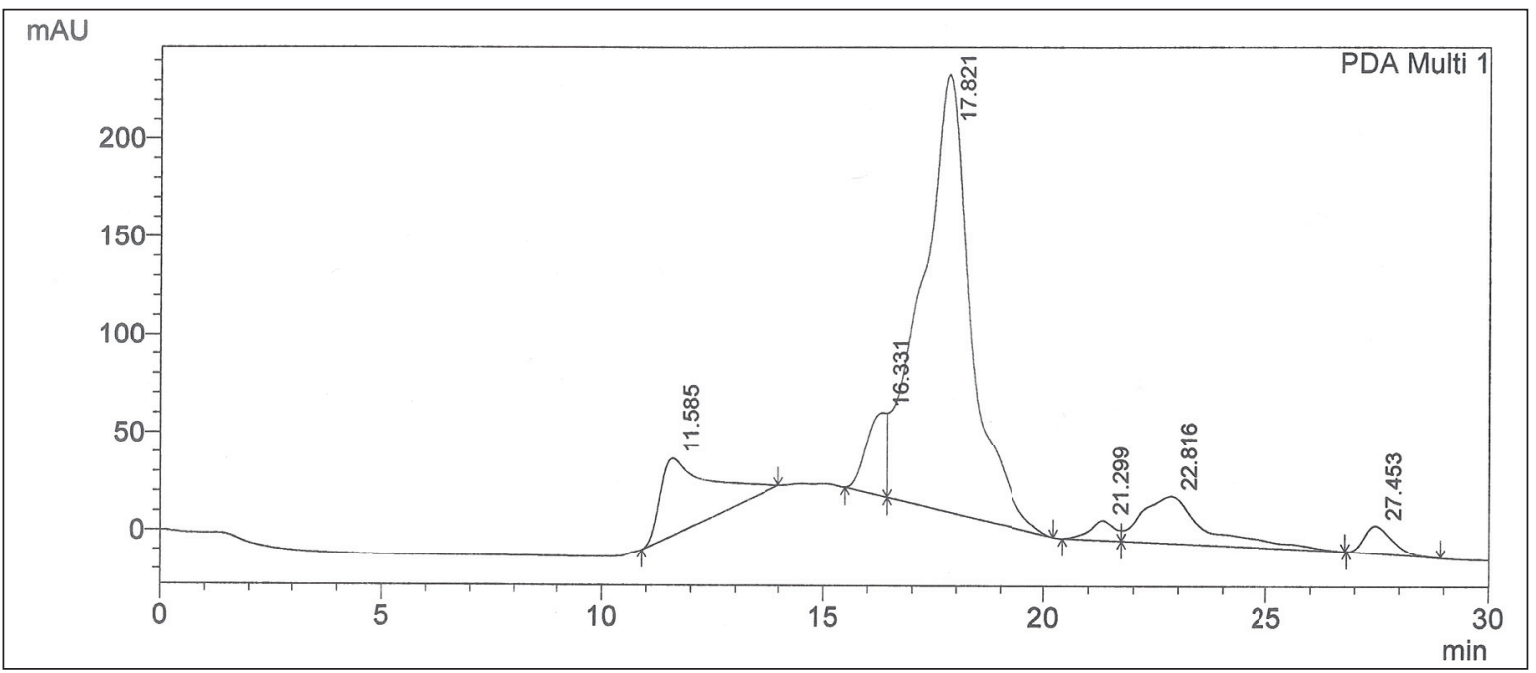

1: Chromatogram of the control sample (pure wheat flour), peak RT $11.585=$ glutenins, peak RT $16.331=$ gliadins, peak RT $17.821=$ gliadins, peak RT 21.299=albumins + globulins, peak RT 22.816=albumins + globulins, peak RT $27.453=$ albumins + globulins

III: Peak characteristics (retention time, area) for combination reducing and oxidising agent

\begin{tabular}{lcccrr}
\hline \multicolumn{1}{c}{ Sample } & $\begin{array}{c}\text { Ret. Time } \\
(\mathbf{m i n})\end{array}$ & $\begin{array}{c}\text { Control } \\
\text { sample }\end{array}$ & $\mathbf{C 1}^{\mathrm{e}}$ & $\mathbf{C 2}^{\mathrm{f}}$ & $\mathbf{C 3}^{\mathrm{g}}$ \\
\hline Peak characteristics/Protein fraction & & Area $\left(\mathbf{1 0}^{\mathbf{3}}\right)$ & Area $\left(\mathbf{1 0}^{\mathbf{3}}\right)$ & Area $\left(\mathbf{1 0}^{\mathbf{3}}\right)$ & Area $\left(\mathbf{1 0}^{3}\right)$ \\
\hline glutenins & 11. & 3023 & 41 & 21 & 35 \\
gliadins & 16. & 1312 & 7944 & 6102 & 5793 \\
gliadins & 18. & 17192 & 22460 & 23160 & 24265 \\
albumins + globulins & 22. & 391 & 31328 & 34981 & 35954 \\
\hline
\end{tabular}

$\mathrm{Cl}^{\mathrm{e}}$ mixture of flour $(75.19 \% \mathrm{w} / \mathrm{w}+\mathrm{L}$-ascorbic acid $(22.56 \% \mathrm{w} / \mathrm{w})+\mathrm{L}$-cysteine hydrochloride monohydrate $(2.26 \% \mathrm{w} / \mathrm{w})$ $\mathrm{C}^{\mathrm{f}}$ mixture of flour $(73.53 \% \mathrm{w} / \mathrm{w}+\mathrm{L}$-ascorbic acid $(22.06 \% \mathrm{w} / \mathrm{w})+\mathrm{L}$-cysteine hydrochloride monohydrate $(4.41 \% \mathrm{w} / \mathrm{w})$ $\mathrm{C}^{5}$ mixture of flour $(72.46 \% \mathrm{w} / \mathrm{w}+\mathrm{L}$-ascorbic acid $(21.74 \% \mathrm{w} / \mathrm{w})+$ L-cysteine hydrochloride monohydrate $(5.80 \% \mathrm{w} / \mathrm{w})$

IV: Peak characteristics (retention time, area) for combination reducing and oxidising agent

\begin{tabular}{lccccc}
\hline \multicolumn{1}{c}{ Sample } & $\begin{array}{c}\text { Ret. Time } \\
(\mathbf{m i n})\end{array}$ & $\begin{array}{c}\text { Control } \\
\text { sample }\end{array}$ & IDY $^{\mathbf{h}}$ & IDY2 $^{\mathbf{i}}$ & IDY3 $^{\mathbf{j}}$ \\
\hline Peak characteristics/Protein fraction & & Area $\left(\mathbf{1 0}^{\mathbf{3}}\right)$ & Area $\left(\mathbf{1 0}^{\mathbf{3}}\right)$ & ${\text { Area }\left(\mathbf{1 0}^{3}\right)}^{\text {Area }\left(\mathbf{1 0}^{\mathbf{3}}\right)}$ \\
\hline glutenins & 12. & 3023 & 1408 & 1162 & 855 \\
gliadins & 18. & 17192 & 22391 & 26378 & 27408 \\
albumins + globulins & 22. & 391 & 23446 & 21289 & 21123 \\
\hline
\end{tabular}

${ }^{k}$ Note: The value of the inactivated dry yeast sample is 10 times higher so that its reducing effect could be compared with that of L-cysteine hydrochloride monohydrate

IDY $^{\mathrm{h}}$ mixture of flour $(62.50 \% \mathrm{w} / \mathrm{w}+\mathrm{L}$-ascorbic acid $(18.75 \% \mathrm{w} / \mathrm{w})+$ inactivated dry yeast $(18.75 \% \mathrm{w} / \mathrm{w})$

IDY2 ${ }^{i}$ mixture of flour $(55.56 \% \mathrm{w} / \mathrm{w}+\mathrm{L}$-ascorbic acid $(16.67 \% \mathrm{w} / \mathrm{w})+$ inactivated dry yeast $(27.78 \% \mathrm{w} / \mathrm{w})$

IDY $^{3}$ mixture of flour $(50.00 \% \mathrm{w} / \mathrm{w}+\mathrm{L}$-ascorbic acid $(15.00 \% \mathrm{w} / \mathrm{w})+$ inactivated dry yeast $(35.00 \% \mathrm{w} / \mathrm{w})$

dually increasing (in comparation with $\mathrm{Cl}$; about 7\%) in the sample C3 with the highest concentration (5.80\% w/w) of L-cysteine hydrochloride monohydrate. Comparison with the control sample of flour showed that the presence of L-cysteine hydrochloride monohydrate in the sample caused a decrease (about 99\%) in the peak areas of the corresponding glutenins. In contrast, the peaks of gliadins in the $18^{\text {th }}$ minute (C1 23\%, C2 26\%, C3 29\%), albumins and globulins (about 99\%) increased. L-cysteine hydrochloride monohydrate is able to reduce the molecular weight of glutenin polymers by SH/SS interchange reactions. Similar information about ability of reducing agents to promote $\mathrm{SH} / \mathrm{SS}$ interchange reactions was mentioned by authors (Morita et al., 1996; Joye et al., 2009).

Table IV shows that with the increasing amount of inactivated dry yeast, there is a decrease in the peak areas of glutenins (in comparation with IDY1; IDY2 17\%, IDY3 39\%), albumins and globulins (in comparation with IDY1; IDY2 9\%, IDY3 10\%). On the contrary, there was an apparent increase (in comparation with IDY1; IDY2 15\%, IDY3 18\%) in the peak areas of gliadins.

The values in Tables III and IV show that the mixture of flour + L-ascorbic acid + L-cysteine hy- 
drochloride monohydrate had a stronger oxidising effect and thus a more significant impact on the viscosity and extensibility of dough. Increased compactness of dough and thus better rheological properties can be expected in the dough which is prepared from the mixture of flour + L-ascorbic acid + inactivated dry yeast.

Table V illustrates the differences between SEHPLC spectra of proteinaceous fractions for the same amount of combinations of oxidising and reducing agents added.

Table V illustrates that the proportion of the peak areas of glutenins (about 97\%) and gliadins (about $12 \%$ ) is always higher in the samples (IDY1-IDY3), which means that these doughs will be of better quality than those prepared from the mixture of flour + L-ascorbic acid + L-cysteine hydrochloride monohydrate. In contrast, the proportion of peak areas cor- responding to albumins and globulins is higher in the samples (C1-C3; C1 25\%, C2 39\%, C3 41\%).

Tables VI-VII illustrate the characteristics of SEHPLC spectra of proteins in pure flour in comparison with different combinations of reducing and oxidising agents added.

Table VI shows that the peak areas of glutenins and gliadins decrease with the increasing amount of the mixture of flour + L-ascorbic acid + L-threonine. First, the peak areas of albumins and globulins increased rapidly (in comparation with control sample; about 98\%) in sample THI and then decreased slowly in samples (TH2-TH4; in comparation with TH1; TH2 4\%, TH3 13\%, TH4 13\%). Cross-linking of the gluten network was stronger with increasing amount of the mixture of flour + L-ascorbic acid + L-threonine. Its mean that it was difficult to extract protein fractions from the blend of flour and addditives.

V: Peak characteristics (retention time, area) for combination reducing and oxidising agent

\begin{tabular}{|c|c|c|c|c|c|c|c|}
\hline Samples & $\begin{array}{c}\text { Ret. Time } \\
\text { (min) }\end{array}$ & $\mathrm{Cl}^{\mathrm{e}}$ & IDY $^{\text {h }}$ & $\mathrm{C} 2^{\mathrm{f}}$ & IDY2 $2^{\mathrm{i}}$ & $\mathrm{C}^{\mathrm{g}}$ & IDY $^{j}$ \\
\hline Peak characteristics/Protein fraction & & \multicolumn{2}{|c|}{ Area $\left(10^{3}\right)$} & \multicolumn{2}{|c|}{ Area $\left(10^{3}\right)$} & \multicolumn{2}{|c|}{ Area $\left(10^{3}\right)$} \\
\hline glutenins & 12. & 41 & 1408 & 21 & 1162 & 35 & 855 \\
\hline gliadins & 18. & 22460 & 22391 & 23160 & 26378 & 24265 & 27408 \\
\hline albumins + globulins & 22. & 31328 & 23446 & 34981 & 21289 & 35954 & 21123 \\
\hline
\end{tabular}

kNote: The value of the inactivated dry yeast sample is 10 times higher so that its reducing effect could be compared with that of L-cysteine hydrochloride monohydrate

$\mathrm{Cl}^{\mathrm{e}}$ mixture of flour $(75.19 \% \mathrm{w} / \mathrm{w}+\mathrm{L}$-ascorbic acid $(22.56 \% \mathrm{w} / \mathrm{w})+\mathrm{L}$-cysteine hydrochloride monohydrate $(2.26 \% \mathrm{w} / \mathrm{w})$ $\mathrm{C}^{\mathrm{f}} \quad$ mixture of flour $(73.53 \% \mathrm{w} / \mathrm{w}+\mathrm{L}$-ascorbic acid $(22.06 \% \mathrm{w} / \mathrm{w})+\mathrm{L}$-cysteine hydrochloride monohydrate $(4.41 \% \mathrm{w} / \mathrm{w})$ $\mathrm{C}^{\mathrm{g}}$ mixture of flour $(72.46 \% \mathrm{w} / \mathrm{w}+\mathrm{L}$-ascorbic acid $(21.74 \% \mathrm{w} / \mathrm{w})+\mathrm{L}$-cysteine hydrochloride monohydrate $(5.80 \% \mathrm{w} / \mathrm{w})$ IDY $1^{\mathrm{h}}$ mixture of flour $(62.50 \% \mathrm{w} / \mathrm{w}+\mathrm{L}$-ascorbic acid $(18.75 \% \mathrm{w} / \mathrm{w})+$ inactivated dry yeast $(18.75 \% \mathrm{w} / \mathrm{w})$ IDY2 ${ }^{\mathrm{i}}$ mixture of flour $(55.56 \% \mathrm{w} / \mathrm{w}+\mathrm{L}$-ascorbic acid $(16.67 \% \mathrm{w} / \mathrm{w})+$ inactivated dry yeast $(27.78 \% \mathrm{w} / \mathrm{w})$ IDY3 $3^{\mathrm{j}}$ mixture of flour $(50.00 \% \mathrm{w} / \mathrm{w}+\mathrm{L}$-ascorbic acid $(15.00 \% \mathrm{w} / \mathrm{w})+$ inactivated dry yeast $(35.00 \% \mathrm{w} / \mathrm{w})$

VI: Peak characteristics (retention time, area) for combination reducing and oxidising agents

\begin{tabular}{|c|c|c|c|c|c|c|}
\hline Sample & $\begin{array}{l}\text { Ret. Time } \\
\text { (min) }\end{array}$ & $\begin{array}{l}\text { Control } \\
\text { sample }\end{array}$ & $\mathbf{T H 1}^{\mathrm{a}}$ & TH$^{\mathbf{b}}$ & TH3 $^{\mathbf{c}}$ & TH $^{\text {d }}$ \\
\hline Peak characteristics/Protein fraction & & Area $\left(10^{3}\right)$ & Area $\left(10^{3}\right)$ & Area $\left(10^{3}\right)$ & Area $\left(10^{3}\right)$ & Area $\left(10^{3}\right)$ \\
\hline gliadins & 18. & 17192 & 11452 & 10110 & 9067 & 8193 \\
\hline albumins + globulins & 22. & 391 & 23089 & 22175 & 20171 & 20257 \\
\hline
\end{tabular}

$\mathrm{TH}^{\mathrm{a}}$ mixture of flour $(62.50 \% \mathrm{w} / \mathrm{w}+\mathrm{L}$-ascorbic acid $(18.75 \% \mathrm{w} / \mathrm{w})+$ L-threonine $(18.75 \% \mathrm{w} / \mathrm{w})$

$\mathrm{TH}_{2}{ }^{\mathrm{b}}$ mixture of flour $(55.56 \% \mathrm{w} / \mathrm{w}+\mathrm{L}$-ascorbic acid $(16.67 \% \mathrm{w} / \mathrm{w})+$ L-threonine $(27.78 \% \mathrm{w} / \mathrm{w})$

$\mathrm{TH}^{\mathrm{c}}$ mixture of flour $(50.00 \% \mathrm{w} / \mathrm{w}+\mathrm{L}$-ascorbic acid $(15.00 \% \mathrm{w} / \mathrm{w})+$ L-threonine $(35.00 \% \mathrm{w} / \mathrm{w})$

$\mathrm{TH}^{\mathrm{d}}$ mixture of flour $(45.45 \% \mathrm{w} / \mathrm{w}+\mathrm{L}$-ascorbic acid $(13.64 \% \mathrm{w} / \mathrm{w})+\mathrm{L}-$ threonine $(40.91 \% \mathrm{w} / \mathrm{w})$

VII: Peak characteristics (retention time, area) for combination reducing and oxidising agents

\begin{tabular}{|c|c|c|c|c|c|c|}
\hline Sample & $\begin{array}{l}\text { Ret. Time } \\
\text { (min) }\end{array}$ & $\begin{array}{l}\text { Control } \\
\text { sample }\end{array}$ & TR $1^{w}$ & TR2 $^{x}$ & TR3 $3^{y}$ & TR4 $^{z}$ \\
\hline Peak characteristics/Protein fraction & & Area $\left(10^{3}\right)$ & Area $\left(10^{3}\right)$ & Area $\left(10^{3}\right)$ & $\operatorname{Area}\left(10^{3}\right)$ & Area $\left(10^{3}\right)$ \\
\hline gliadins & 18. & 17192 & 11427 & 4815 & 4248 & 4147 \\
\hline albumins + globulins & 22. & 391 & 21652 & 9585 & 8850 & 7989 \\
\hline
\end{tabular}

TRI ${ }^{\mathrm{w}}$ mixture of flour $(62.50 \% \mathrm{w} / \mathrm{w}+\mathrm{L}$-ascorbic acid $(18.75 \% \mathrm{w} / \mathrm{w})+\mathrm{L}-\operatorname{tryptophan}(18.75 \% \mathrm{w} / \mathrm{w})$

TR2 ${ }^{\mathrm{x}}$ mixture of flour $(55.56 \% \mathrm{w} / \mathrm{w}+\mathrm{L}$-ascorbic acid $(16.67 \% \mathrm{w} / \mathrm{w})+\mathrm{L}$-tryptophan $(27.78 \% \mathrm{w} / \mathrm{w})$

TR $^{y}$ mixture of flour $(50.00 \% \mathrm{w} / \mathrm{w}+\mathrm{L}$-ascorbic acid $(15.00 \% \mathrm{w} / \mathrm{w})+$ L-tryptophan $(35.00 \% \mathrm{w} / \mathrm{w})$

TR4 ${ }^{z}$ mixture of flour (45.45\% w/w + L-ascorbic acid (13.64\% w/w) + L-tryptophan (40.91\% w/w) 
VIII: Peak characteristics (retention time, area) for combination reducing and oxidising agents

\begin{tabular}{|c|c|c|c|c|c|c|c|c|c|c|}
\hline & am & (m & THI $^{\mathrm{a}}$ & [R] & $\Gamma H 2^{b}$ & TR2 $^{x}$ & $\mathrm{TH}^{\mathrm{c}}$ & TR3 $3^{y}$ & $\mathbf{H} 4^{\mathrm{d}}$ & TR4 ${ }^{z}$ \\
\hline \multicolumn{3}{|c|}{ Peak characteristics/Protein fraction } & \multicolumn{2}{|c|}{ Area $\left(10^{3}\right)$} & \multicolumn{2}{|c|}{ Area $\left(10^{3}\right)$} & \multicolumn{2}{|c|}{ Area $\left(10^{3}\right)$} & \multicolumn{2}{|c|}{ Area $\left(10^{3}\right)$} \\
\hline gluter & & 12. & & & & & & & & 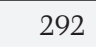 \\
\hline Jlia & & 18. & 1452 & & 1 & & & & & \\
\hline llbe & & 22. & 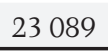 & & & & & & & \\
\hline \multicolumn{11}{|c|}{$\begin{array}{l}\text { TH1/TRla,w mixture of flour }(62.50 \% \mathrm{w} / \mathrm{w}+\mathrm{L} \text {-ascorbic acid }(18.75 \% \mathrm{w} / \mathrm{w})+\text { L-threonine }(18.75 \% \mathrm{w} / \mathrm{w}) / \text { L-tryptophan } \\
(18.75 \% \mathrm{w} / \mathrm{w})\end{array}$} \\
\hline & \multicolumn{10}{|c|}{$\begin{array}{l}\text { mixture of flour }(55.56 \% \mathrm{w} / \mathrm{w}+\text { L-ascorbic acid }(16.67 \% \mathrm{w} / \mathrm{w})+\text { L-threonine }(27.78 \% \mathrm{w} / \mathrm{w}) / \text { L-tryptophan } \\
(27.78 \% \mathrm{w} / \mathrm{w})\end{array}$} \\
\hline$c, \mathrm{y}$ & \multicolumn{10}{|c|}{$\begin{array}{l}\text { mixture of flour }(50.00 \% \mathrm{w} / \mathrm{w}+\mathrm{L} \text {-ascorbic acid }(15.00 \% \mathrm{w} / \mathrm{w})+\text { L-threonine }(35.00 \% \mathrm{w} / \mathrm{w}) / \text { L-tryptophan } \\
(35.00 \% \mathrm{w} / \mathrm{w})\end{array}$} \\
\hline H4/TR4', z & \multicolumn{10}{|c|}{$\begin{array}{l}\text { mixture of flour (45.45\% w/w + L-ascorbic acid (13.64\% w/w) + L-threonine (40.91\% w/w)/ L-tryptophan } \\
(40.91 \% \mathrm{w} / \mathrm{w})\end{array}$} \\
\hline
\end{tabular}

Table VII illustrates that, in comparison with the control dough, larger areas of proteinaceous fractions were detected in the lowest amount of the mixture of flour + L-ascorbic acid + L-tryptophan (TR1). The peak areas of gliadins (in comparation with TR1; TR2 58\%, TR3 $63 \%$, TR4 64\%), albumins and globulins (in comparation with TR1; TR2 56\%, TR3 $59 \%$, TR4 63\%) were decreasing rapidly with the increasing amount of this mixture. Nevertheless, the amount of albumins and globulins was higher (about 96\%) than in the control sample.

Tables VI and VII show that mixtures of flour + L-ascorbic acid + L-tryptophan (TRl-TR4) had stronger oxidising effects on the gluten network than mixtures of flour + L-ascorbic acid + L-threonine (TH1-TH4). The possibility to detect glutenin fractions was gradually worsen with the increasing amount of L-tryptophan in mixture.

Table VIII illustrates the differences between proteinaceous fractions for the same amount of the mixtures with different kind of oxidising agent added.

Table VIII illustrates that the samples (TH1-TH4) show a higher ability to extract glutenin, gliadin, albumin and globulin fractions. Higher amount of the mixture of flour + L-ascorbic acid + L-tryptophan (TR3-TR4) led to more intensive gluten networking and thus the extraction of glutenins from the solution was impossible.

\section{CONCLUSION AND PRACTICAL APPLICATION}

As it is clear from the results, mixtures of flour + L-ascorbic acid + L-cysteine hydrochloride monohydrate had a stronger reducing effect and thus a more significant impact on the viscosity and extensibility of dough. Increased compactness and thus better rheological properties (elasticity and extensibility of dough) is expected in doughs with mixtures of flour + L-ascorbic acid + inactivated dry yeast. Evaluation of the differences in the areas of proteinaceous fractions presents in the samples with the same amount of combinations of the oxidising and reducing agents plus flour observed showed that the proportion of peak areas of glutenins and gliadins is always higher in the samples (IDY1IDY3). It means that these doughs will be of better quality than those with mixtures of flour + L-ascorbic acid + L-cysteine hydrochloride monohydrate. On the other hand, the proportion of the peak areas of albumins and globulins is higher in the samples (C1-C3). Thus, these doughs will have a decreased volume in comparison with doughs with the mixtures of flour + L-ascorbic acid + inactivated dry yeast.

It was detected that, within the range of combinations of oxidising and reducing agents tested, the mixture of flour + L-ascorbic acid + L-tryptophan had stronger oxidising effects on the gluten network. With the increasing amount of L-tryptophan in mixtures, it was gradually impossible to detect the individual proteinaceous fractions. Furthermore, while observing the differences in the areas of proteinaceous fractions with the same amount and combinations of oxidising and reducing agents, it was detected that the samples with the mixtures of flour + L-ascorbic acid + L-threonine show a better ability to extract glutenin, gliadin, albumin and globulin subunits. Thus, it can be said that the mixtures of flour + L-ascorbic acid + L-tryptophan will have better oxidising effects on dough. Higher concentrations of L-tryptophan in mixture lead to more intensive gluten networking and thus the extraction and further detection of proteinaceous fractions was impossible. Baker products from these mixtures will have a greater volume and better porosity than doughs with the mixtures of flour + L-ascorbic acid + L-threonine. However, because of good oxidising abilities of both combinations of the mixtures, both alternatives can be recommended depending on the quality of the flour required.

\section{Practical application}

Properties of wheat flour are able to improve on required quality by using of combination of individual reducing and oxidising agents as additives chosen by us (L-cysteine hydrochloride monohydrate, inactivated dry yeast, L-ascorbic acid, L-threonine, L-tryptophan) and it is reflecting in quality of prepared doughs and bakery products. 


\section{SOUHRN}

Změny zastoupení bílkovinných frakcí v pšeničné mouce za přídavku odlišných kombinací oxidačních a redukčních činidel

Byl zkoumán vliv různých kombinací redukčních a oxidačních činidel (L-cysteinu hydrochloridu monohydrátu + L-askorbové kyseliny, inaktivovaného droždí + L-askorbové kyseliny, L-threoninu + L-askorbové kyseliny, L-tryptofanu + L-askorbové kyseliny) na změny v zastoupení gluteninů, gliadinů, albumino̊, globulinů v pšeničné mouce. Do pšeničné mouky byly přidány různé kombinace aminokyselin v odlišných koncentracích. Změny proteinových frakcí způsobené jednotlivými kombinacemi aminokyselin v odlišných koncentracích oproti kontrolnímu vzorku (čistá pšeničná mouka) byly vyhodnoceny pomocí Size-Exclusion High-Performance Liquid Chromatography (SE-HPLC). Bylo zjištěno, že směs mouky + L-askorbové kyseliny + L-cysteinu hydrochloridu monohydrátu měla silnější redukční účinek na těsto než směs mouky + L-askorbové kyseliny + inaktivovaného droždí. Směs mouky + L-askorbové kyseliny + L-tryptofanu však měla silnější oxidační účinek na těsto než směs mouky + L-askorbové kyseliny + L-threoninu.

aminokyselina, oxidační činidlo, redukční činidlo, mouka, směs

This work was kindly supported by a project of The Ministry of Education, Youth and Sports of The Czech Republic (Grants no. MSM 7088352101 and MSM 2532885901).

\section{APPENDIX}

\section{An alphabetical list of abbreviations}

Cl mixture of flour $(75.19 \% \mathrm{w} / \mathrm{w}+\mathrm{L}$-ascorbic acid $(22.56 \% \mathrm{w} / \mathrm{w})+$ L-cysteine hydrochloride monohydrate $(2.26 \% \mathrm{w} / \mathrm{w})$

C2 mixture of flour $(73.53 \% \mathrm{w} / \mathrm{w}+\mathrm{L}$-ascorbic acid $(22.06 \% \mathrm{w} / \mathrm{w})+$ L-cysteine hydrochloride monohydrate $(4.41 \% \mathrm{w} / \mathrm{w})$

C3 mixture of flour $(72.46 \% \mathrm{w} / \mathrm{w}+\mathrm{L}$-ascorbic acid $(21.74 \% \mathrm{w} / \mathrm{w})+$ L-cysteine hydrochloride monohydrate $(5.80 \% \mathrm{w} / \mathrm{w})$

D250 the drop in pressure at 250 seconds from PrMax minus $20 \%$

D450 the drop in pressure at 450 seconds from PrMax minus $20 \%$

FN Falling number

GC gluten content in dry matter

HMW-GS high molecular weight glutenin subunits

IDY1 mixture of flour $(62.50 \% \mathrm{w} / \mathrm{w}+\mathrm{L}$-ascorbic acid $(18.75 \% \mathrm{w} / \mathrm{w})+$ inactivated dry yeast $(18.75 \% \mathrm{w} / \mathrm{w})$

IDY2 mixture of flour $(55.56 \% \mathrm{w} / \mathrm{w}+\mathrm{L}$-ascorbic acid $(16.67 \% \mathrm{w} / \mathrm{w})+$ inactivated dry yeast $(27.78 \% \mathrm{w} / \mathrm{w})$

IDY3 mixture of flour $(50.00 \% \mathrm{w} / \mathrm{w}+\mathrm{L}$-ascorbic acid $(15.00 \% \mathrm{w} / \mathrm{w})+$ inactivated dry yeast $(35.00 \% \mathrm{w} / \mathrm{w})$

L extensibility

LMW-GS low molecular weight glutenin subunits

$\mathrm{mb} \quad$ millibar

MC moisture content

min. minute

$\mathrm{mm} \quad$ millimetre

$\mathrm{P} \quad$ tenacity

$\mathrm{pH} \quad \mathrm{pH}$

$\mathrm{P} / \mathrm{L} \quad$ configuration ratio

PrMax maximum pressure

RT retention time

S second

SDS Sedimentation test according to Axford

SE-HPLC Size Exclusion High performance liquid chromatography

SH sulfhydryl group

SS disulfide bond

TH1 mixture of flour $(62.50 \% \mathrm{w} / \mathrm{w}+\mathrm{L}$-ascorbic acid $(18.75 \% \mathrm{w} / \mathrm{w})+\mathrm{L}$-threonine $(18.75 \% \mathrm{w} / \mathrm{w})$

TH2 mixture of flour $(55.56 \% \mathrm{w} / \mathrm{w}+\mathrm{L}$-ascorbic acid $(16.67 \% \mathrm{w} / \mathrm{w})+\mathrm{L}$-threonine $(27.78 \% \mathrm{w} / \mathrm{w})$

TH3 mixture of flour $(50.00 \% \mathrm{w} / \mathrm{w}+\mathrm{L}$-ascorbic acid $(15.00 \% \mathrm{w} / \mathrm{w})+$ L-threonine $(35.00 \% \mathrm{w} / \mathrm{w})$

TH4 mixture of flour $(45.45 \% \mathrm{w} / \mathrm{w}+\mathrm{L}$-ascorbic acid $(13.64 \% \mathrm{w} / \mathrm{w})+$ L-threonine $(40.91 \% \mathrm{w} / \mathrm{w})$

Tol time that pressure is higher than PrMax minus 20\%

TPrMax time to reach maximum pressure

TR1 mixture of flour $(62.50 \% \mathrm{w} / \mathrm{w}+\mathrm{L}$-ascorbic acid $(18.75 \% \mathrm{w} / \mathrm{w})+$ L-tryptophan $(18.75 \% \mathrm{w} / \mathrm{w})$ 
TR2

TR3

TR4

W mixture of flour $(55.56 \% \mathrm{w} / \mathrm{w}+\mathrm{L}$-ascorbic acid (16.67\% w/w) + L-tryptophan $(27.78 \% \mathrm{w} / \mathrm{w})$ mixture of flour $(50.00 \% \mathrm{w} / \mathrm{w}+\mathrm{L}$-ascorbic acid $(15.00 \% \mathrm{w} / \mathrm{w})+$ L-tryptophan $(35.00 \% \mathrm{w} / \mathrm{w})$ mixture of flour (45.45\% w/w + L-ascorbic acid (13.64\% w/w) + L-tryptophan (40.91\% w/w) deformation energy

\section{REFERENCES}

BIEBAUT, D., 1991: Flour improvers and raising agents. Food Additive User's Handbook, Blackie Academic \& Professional, London, 242-256.

BLOKSMA, A. H., 1972: The relation between the thiol disulfide contents of dough and its rheological properties. Cereal Chemistry, 49: 104-117. ISSN: 0009-0352

CIAFFI, M., TOZZI, L., LAFIANDRA, D., 1996: Relationship between flour protein composition determined by size-exclusion high-performance liquid chromatography and dough rheological parameters. Cereal Chemistry, 73: 346-351. ISSN 0009-0352

DACHKEVITCH, T., AUTRAN, J. C., 1989: Prediction of Baking Quality of Bread Wheats in Breeding Programs by Size-Exclusion High-Performance Liquid Chromatography. Cereal Chemistry, 66: 448-456. ISSN 0009-0352

DONG, W., HOSENEY, R. C., 1995: Effects of Certain Breadmaking Oxidants and Reducing Agents on Dough Rheological Properties. Cereal Chemisty, 72: 58-64. ISSN 0009-0352

D'OVIDIO, R., MASCI, S., 2004: The low-molecularweight glutenin subunits of wheat gluten. Journal of Cereal Science, 39: 321-339. ISSN 0733-5210

FIELD, J. M., SHEWRY, P. R., BURGESS, S. R., FORDE, J., PARMAR, S., MIFLIN, B. J., 1983a: The presence of high molecular weight aggregates in the protein bodies of developing endosperms of wheat and other cereals. Journal of Cereal Science, 1: 33-41. ISSN 0733-5210

FIELD, J. M., SHEWRY, P. R., MIFLIN, B. J., 1983b: Solubilisation and characterisation of wheat gluten proteins: Correlations between the amount of aggregated proteins and baking quality. Journal of the Science of Food and Agriculture, 34: 370-377. ISSN: 0022-5142

GOLIAN, J., 2009: Princípy stratégie výživovej politiky. In Biotechnológie, výživa a zdravie (Keresteš et al.) Eminent s.r.o., Považská Bystrica, 29-34. ISBN 978-80-970205-9-0

GUPTA, R. B., KHAN, K., MACRITCHIE, F., 1993: Biochemical basis of flour properties in bread wheats. I. Effects of variation in the quantity and size distribution of polymeric protein. Journal of Cereal Science, 18: 23-41. ISSN 0733-5210

GUPTA, R. B., POPINEAU, Y., LEFEBVRE, J., CORNECT, M., LAWRENCE, G. J., MACRITCHIE, F., 1995: Biochemical basis of flour properties in bread wheats. II. Changes in polymeric protein formation and dough/gluten properties associated with the loss of low Mr or high Mr glutenin subunits. Journal of Cereal Science, 21: 103-116. ISSN 0733-5210

JANSSEN, A. M., VLIET, T., VEREIJKEN, J. M., 1996: Rheological behaviour of wheat glutens at small and large deformations. Effect of gluten composition. Journal of Cereal Science, 23: 33-42. ISSN 0733-5210

JOYE, I. J., LAGRAIN, B., DELCOUR, J. A., 2009: Endogenous redox agents and enzymes that affect protein network formation during breadmaking-A review, Journal of Cereal Science, 50: 1-10. ISSN 0733-5210

KHATKAR, B. S., BELL, A. E., SCHOFIELD, J. D., 1995: The dynamic rheological properties of glutens and gluten sub-fractions from wheats of good and poor bread-making quality. Journal of Cereal Science, 22: 29-44. ISSN 0733-5210

MENDICHI, R., FISICHELLA, S., SAVARINO, A., 2008: Molecular weight, size distribution and conformation of Glutenin from different wheat cultivars by SEC-MALLS. Journal of Cereal Science, 48: 486-493. ISSN 0733-5210

MORITA, N., NAKATA, K., HAMAUZU, Z., TOYOSAWA, I., 1996: Effect of alpha - Glucosyl Rutin as Improvers for Wheat Dough and Breadmaking. Cereal Chemistry, 73: 99-104. ISSN 0009-0352

RHAZI, L., BODARD, A. L., FATHOLLAHI, B., AUSSENAC, T., 2009: High throughput microchipbased separation and quantitation of high-molecular-weight glutenin subunits. Journal of Cereal Science, 49: 272-277. ISSN 0733-5210

UTHAYAKUMARAN, S., GRAS, P. W., STODDARD, F. L., BEKES, F., 1999: Effect of varying protein content and glutenin-to-gliadin ratio on the functional properties of wheat dough. Cereal Chemistry, 76: 389-394. ISSN 0009-0352

VERAVERBEKE, W. S., VERBRUGGEN, I. M., DELCOUR, J. A., 1998: Effects of increased high molecular weight glutenin subunits content of flour on dough mixiny behavior and breadmaking. Journal of Agricultural and Food Chemistry, 46: 4830-4835. ISSN 0021-8561

WEEGELS, P. L., HAMER, R. J., SCHOFIELD, J. D., 1996: Functional properties of wheat glutenin. Journal of Cereal Science, 23: 1-17. ISSN 0733-5210

WRIGLEY, C. W., 1996: Giant proteins with flour power. Nature, 381: 738-739. ISSN 0028-0836

\section{Address}

Ing. Pavlína Pečivová, Ph.D., doc. Ing. Jan Hrabě, Ph.D., Ústav technologie a mikrobiologie potravin, Fakulta technologická, Univerzita Tomáše Bati ve Zlíně, nám. T. G. Masaryka, 275, 76272 Zlín, Česká republika, e-mail: pecivova@ft.utb.cz, Mgr. Iva Burešová, Ph.D., Agrotest fyto, Kroměříž, Havlíčkova 2787/121, 76701 Kroměříž, Česká republika 